\title{
Methodological framework to assess military rammed-earth walls. The case of Seville city ramparts
}

\author{
J. Canivell ${ }^{1}$, A. Jaramillo-Morilla ${ }^{2}$, E.J. Mascort-Albea² \& R. Romero-Hernández ${ }^{2}$ \\ ${ }^{I}$ Department of Architectural Construction 2. Higher Technical School of Building Engineering. \\ Universidad de Sevilla. Avenida de Reina Mercedes 4A, 41012 Sevilla, Spain. jacanivell@us.es \\ ${ }^{2}$ Department of Building Structures and Soil Engineering. Higher Technical School of Architecture. \\ Universidad de Sevilla. Avenida de Reina Mercedes 2, 41012 Sevilla, Spain. jarami@us.es, \\ emascort@us.es, rociorome@us.es
}

\begin{abstract}
:
The high density of historic rammed earth military samples in the Iberian Peninsula is mainly due to Almoravid and Almohad presence during the $11^{\text {th }}$ and $13^{\text {rd }}$ centuries.

The aim of this paper is to provide a methodological framework that enables the assessment of these sites, using the city walls of Seville as a case study. Hence, multi-scale and multidisciplinary approaches have been developed employing methodologies based on the use of CADGIS-BIM digital models, conceived as a Digital Cartographic Management (DCM) protocol.

This research will contribute to a better knowledge of this medieval heritage that will enable the development of future intervention criteria and the creation of preventive conservation strategies. The scientific knowledge achieved will also contribute to the regulation and standardization of the restoration of monuments built with rammed earth. Conservation and repair of historic rammed earth sites should only be undertaken if there is a good understanding of the consequences of any intervention technique.
\end{abstract}

\section{INTRODUCTION}

The historic wall of Seville is one of the most important urban symbols of the Muslim presence in the city. Its Islamic origin design and its great area are the result of the extension of the previous Roman enclosure, which has no visible remains today. Thus, the medieval fortification of Seville consisted of an urban fortress occupying a 17 hectares site and a walled enclosure, which during the period of Almohad domination reached an occupation of 273 hectares (Valor Piechotta, 2014). Additionally, this monument also stands out for its material nature, based on the use of soils by means of the tapial technique. This consist of a reusable formwork within which earth is manually compacted. While the walls of residential or civil buildings are around $40-60 \mathrm{~cm}$, in the case of fortifications, the thickness is usually well over one meter.

Once built, the urban rampart of Seville has suffered partial transformations, often related to the conservation and repair of walls and the renovation of its gates. However, from the second half of the $19^{\text {th }}$ century, it began a continuous process of demolitions which affected several parts of the monument, as a consequence of the growing that the city experienced (Suárez Garmendia, 1986; Morales, 2013). Consequently, of the more than 6,000 meters from the original perimeter, only about 2,000 meters remain (Valor Piechotta, 2014). Within the preserved parts, a significant percentage corresponds to the sector located in the northern area of the old historical center, which is placed between the old gates of Cordoba and Macarena. This sector is known by the name of Muralla de la Macarena and was declared National Historical Monument in January 1908. Precisely, this consideration was requested in order to avoid their demolition. As a result, a 500 meter long perimeter stands for one outstanding monument consisting of walls, barbicans, towers, gates portholes (Suárez Garmendia, 1986).

In this context, it is necessary to point out that the interventions carried out during the $19^{\text {th }}$ and $20^{\text {th }}$ centuries have revealed conservation work as a punctual and unplanned task. This question, as well as the weak response of certain restorations that have been performed with restoring techniques not totally compatible to the original and has therefore resulted in a deficient state of conservation. This issue can be checked through studies about interventions undertaken from 
the 1980s to the most recent (García-Tapial, 2006; Canivell and Graciani, 2014; Graciani and Canivell, 2014). Nowadays, erosion, loss of material, sandblasting, dirt, loss of cohesion or partial detachments of blocks and merlons are common. Even though these affections do not structurally compromise this thick masonry wall, they do totally undermine this valuable and protected heritage asset, and may even accidentally affect the integrity of visitors due to the proximity of the public pedestrian road.

The abovementioned situation exemplifies the need of an integral look for the conservation, maintenance and dissemination of the values of the patrimonial architecture built on earth. This question should be channeled through a common plan applied to the Macarena sector, through a strategy of collaboration proposed by the City Planning Department and the University of Seville. The objective of the work is to propose a methodological procedure that facilitates a progressive follow-up of the results that will be obtained during the future intervention work on the building (Canivell, Jaramillo-Morilla, Mascort-Albea, \& Romero-Hernández, 2019).

\section{METHODOLOGICAL APPROACH AND OBJECTIVES}

Nowadays, the use of digital models for the management of information related to cultural heritage constitutes a very relevant research line. Additionally, the interoperability between different tools such as Computer Aided Design (CAD), and more recently, Building Information Modelling (BIM) and Geographic Informatic Systems (GIS) can provide a very complete graphic, parametric and spatial control of any cultural assets. Based on this approach, the authors of this document define Digital Cartographic Management (DMC) as the use of geographical tools for the creation of spatial and architectonic databases related to build heritage. This is achieved through a multi-scale conception of the use of GIS that ranges from territorial and urban to an architectural scale that allows defining through geographical entities the main spatial and architectural components of a building, as well as the movable assets contained therein.

Precisely, in the use of geographical techniques at a level of architectural detail resides the novelty of the current approach. Thus, it is possible to fill a gap of information existing in most spatial geo-viewers and generate in a flexible and affordable way new digital and simplified models that analyze the particularities of buildings (Mascort-Albea, 2018), constituting a solid basis for further 3D developments on BIM models or CityGML formats (Hidalgo Sánchez, 2018). Through the developed experiences in various case studies, it has been shown that this strategy contributes to the preventive conservation of historic buildings, from a transversal perspective. In this sense, the use of GCD stands out for the development of tourist applications for heritage interpretation (Mascort-Albea et al., 2016), cataloguing of risk of abandonment buildings (Mascort-Albea and Meynier-Philip, 2017) or the multidisciplinary analysis of historical typologies (Mascort-Albea, 2017).

Based on the above considerations, a predictive monitoring of the historic wall of Seville is proposed and based on the following methodological approach:

- A common methodological framework for evaluating the state of the study case, as a basis for (1) improving the management of the knowledge acquired about this monument, (2) knowing and diagnosing its current state of conservation and (3) establishing more effective and unitary criteria for action.

- Assess the risks and vulnerabilities of the wall with in order to detect the critical sectors and prioritize the interventions.

- A technical protocol to manage the maintenance of the wall, based on a procedure for monitoring physical-mechanical parameters and on the same cartographic-digital models.

- A tool that, based on the use of interactive cartographic-digital models and institutional web platforms, serves to spread the heritage values of the historic Seville city wall.

\section{WORKPLAN AND GDC SYSTEM STRUCTURE}

The proposed methodological procedure will be developed through a work plan, which contains the following phases: 
A.Documentary phase. Documentation on archaeological interventions will be compiled and analysed. Additionally, the historical documentation about the evolution of the monument, as well as the technical restoration will be studied.

B. Digitalization phase. Starting from the available graphic documentation, mainly plans and elevations, a detailed cartography will be generated. Especially significant are the elevations of the walls from the archaeological reports, where specific aspects of the wall are detailed.

As a complementary resource, a digital scan could be employed to make a digital 3D model. As a result, not only the volume, but also rectified images of each elevation with real textures will be obtained. Starting from the digital cartography designed by the Urban Development Department of Seville (GUS), the detailed elements not already considered will be completed.

C. Structure of the Digital Cartographic Management (GCD) system. Based on the characterization and evaluation procedure carried out by Canivell (Canivell and Graciani, 2015; Canivell, 2012) and the cartographic representation at architectural scale proposed by Mascort-Albea (Mascort-Albea, 2017, 2018), a geo-referenced spatial database will be structured. The database will include descriptive, constructive and material parameters. At the same time, a standard data collection form will be created. Likewise, a sectorisation of the walls and towers will be designed in logical units at different levels building a related hierarchical tree, where the data collected during the field work and documentation will be dumped (Fig.1).

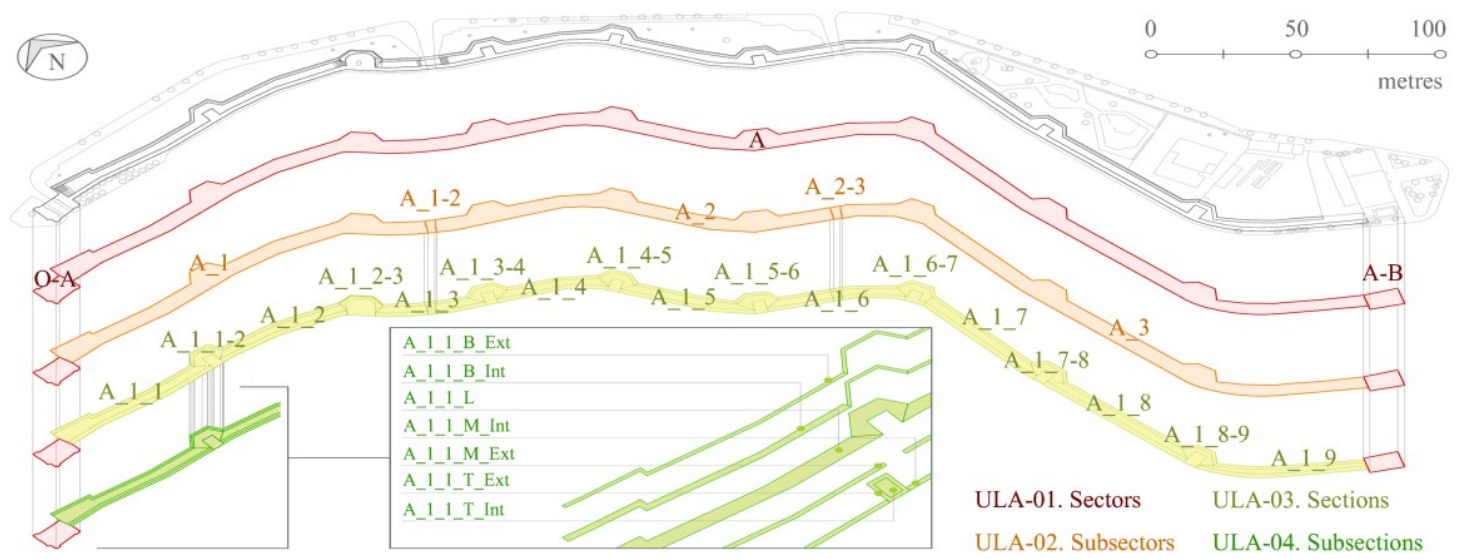

Figure 1. Macarena sector main GDC units. Codes and numbers are related to a hierarchical increase of the architectonic level of detail. Source: Prepared by the authors from IDE Sevilla plans

D. Data collection and characterization. In successive in situ surveys, the available plans will be checked and updated. Afterwards, the characterization studies will be carried out using nondestructive inspection methods, such as thermography and ground-penetrating radar (GPR), despite these data will be analysed at a later stage. Finally, once the vulnerable sectors have been determined, samples will be extracted to be characterised and analysed in the laboratory.

E. Diagnosis and sensorization. A first level preliminary assessment of the current state of conservation and vulnerabilities will be prepared in order to establish the most critical sectors. Next, and starting with the samples from the previous phase, the characterization tests of the samples will be run. At the same time, a prototype of sensors based on Open Access technologies will be developed to monitor the physical-mechanical parameters of the walls (pressure, relative humidity and movements of the masonry, as well as climatological data of the environment).

F. Data uploading, update and analysis. The information upload into the developed GCD system is validated, both the data corresponding to the inspection and those from laboratory tests and inspection methods. The parameters and factors of the GCD system will then be updated in order to carry out a more precise second level risk assessment, in order to establish the critical sectors, action strategies and planning of a conservation and preventive maintenance protocol.

G.Transfer and dissemination of the achieved results. On the basis of the GCD system and by selecting the contents, an interactive guide will be prepared through an institutional website. In this way, the results will be reverted, both to citizens and to those specialized technicians related to the conservation of the built heritage on earth. The institutional tools and open data platforms that GUS has set up for this purpose will be used for this transfer work. 


\section{CONCLUSIONS}

Given the current need to define simple procedures for the conservation and predictive maintenance of cultural assets, strategies are proposed for the widespread use of GIS on an architectural scale. The proposed GDC provides a methodological approach that encourages the use of geographical tools for the detailed analysis of heritage architecture. In this way, the historic wall of Seville due to its extension and urban influence as a great monumental infrastructure, constitutes an ideal case study for the application of the proposed strategies. Through this work, a predictive model has been designed that adapts to the needs of the project, the existing resources and the particular nature of the case study. In this sense, the development of a methodological strategy that seeks to integrate different scales of resolution and disciplinary components, it is required that the work achieve a high degree of graphic, thematic and terminological coherence.

The information will be structured through different thematic components, which due to their transversal nature will serve as an internal working tool for the control and monitoring of the material state of the property, and additionally, employed as an instrument for widespread of the monument through the subsequent technological development of digital applications. Finally, it is observed how the case study adapts to the limits of a work that intends to be a pilot episode. In this way, a preliminary selection of representative elements was made for each work unit, so that they could be significant to extend the model created to the whole city's historic wall.

\section{REFERENCES}

Canivell, J. and Graciani, A. (2014) 'Muralla de Sevilla (1984-2008)', La restauración de la tapia en la Península Ibérica : criterios, técnicas, resultados y perspectivas, pp. 218-221.

Canivell, J. (2012) 'Characterization methodology to efficiently manage the conservation of historical rammed-earth buildings', in C Mileto et al. (eds.) Rammed Earth Conservation. Rammed Earth Conservation. London: Taylor \& Francis Group. pp. 283-288.

Canivell, J. and Graciani, A. (2015) Constructive characterization of historical rammed-earth walls in Almohad fortresses in the ancient Reign of Seville. Arqueologia de la Arquitectura (12) Retrieved from http://arqarqt.revistas.csic.es/index.php/arqarqt/article/view/178

Canivell, J., Jaramillo-Morilla, A., Mascort-Albea, E. J., \& Romero-Hernández, R. (2019). Metodología de evaluación y monitorización del patrimonio basado en la gestión cartográfica digital. La muralla de Sevilla. En M. Di Sivo \& D. Ladiana (Eds.), Le mura urbane crollano: conservazione $e$ manutenzione programmata della cinta muraria dei centri storici. (pp. 119-135). Pisa, Italia: Pisa University Press. https://doi.org/10.12871/97888333917559

García-Tapial, J. (2006) 'Proyecto de rehabilitación de la Muralla de la Macarena. Fase III'. Sevilla.

Graciani, A. and Canivell, J. (2014) 'Revisión de las Intervenciones en Fábricas de Tapia en Andalucía Occidental', in Mileto, C., Vegas, F. (ed.) Restauración de la tapia en la península ibérica. Criterios, técnicas, resultados, perspectivas. General de Ediciones de Arquitectura, pp. 30-41.

Hidalgo Sánchez, F. M. (2018). Interoperabilidad entre SIG y BIM aplicada al patrimonio arquitectónico. Exploración de posibilidades mediante la realización de un modelo digitalizado de la Antigua Iglesia de Santa Lucía y posterior análisis. (Universidad de Sevilla). Retrieved from https://hdl.handle.net/11441/79394

Mascort-Albea, E. J. (2018). Mapas para el patrimonio: caracterización técnica de las iglesias medievales de Sevilla mediante sistemas de información geográfica (SIG) (Universidad de Sevilla). Retrieved from https://idus.us.es/xmlui/handle/11441/70745

Mascort-Albea, E. J. and Meynier-Philip, M. (2017). Strategies for conservation of Religious Heritage in the Metropolitan Area of Lyon/Saint-Étienne (France). Short research stay and methodological transfer. IDA 2017. 1st International Congress on Advanced Doctoral Research in Architecture, 675-684. Retrieved from https://idus.us.es/xmlui/handle/11441/70006

Mascort-Albea, E. J. (2017). Datos geográficos abiertos para la conservación preventiva del patrimonio arquitectónico. revista $P H,(92), 228$. Retrieved from https://doi.org/10.33349/2017.0.3948

Mascort-Albea, E. J. et al. (2016) Sevilla, Patrimonio Mundial: guía cultural interactiva para dispositivos móviles. revista PH. (90), 152. Retrieved from https://doi.org/10.33349/2016.0.3778

Morales, A. J. (2013) 'Un episodio en el derribo de las murallas de Sevilla', Lab.Arte, 25(2), pp.689-700.

Suárez Garmendia, J. M. (1986) Arquitectura y urbanismo en la Sevilla del siglo XIX. Sevilla, España: Diputación Provincial de Sevilla.

Valor Piechotta, M. (2014) 'La muralla medieval de Sevilla. Otra interpretación', in Sevilla Arqueológica. La ciudad en época protohistórica, antigua y andalusí. Sevilla, España: Ayuntamiento de Sevilla. 